\title{
Solar and IMF Effects on Mid-Latitude Ionospheric Electric Fields and foF2
}

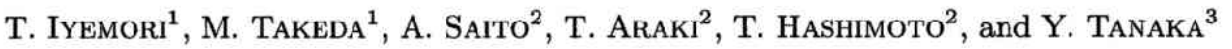 \\ ${ }^{1}$ Data Analysis Center for Geomagnetism and Space Magnetism, Faculty of Science, \\ Kyoto University, Kyoto 606-01, Japan \\ ${ }^{2}$ Geophysical Institute, Faculty of Science, Kyoto University, Kyoto 606-01, Japan \\ ${ }^{3}$ Beppu Geophysical Research Institute, Faculty of Science, Kyoto University, Beppu 874, Japan
}

(Received November 13, 1995; Revised March 8, 1996; Accepted April 16, 1996)

The solar and IMF effects were statistically detected in mid-latitude $(L=1.25)$ ionospheric electric field data obtained by the MU radar. It was found that the IMF- $B_{x}$ component (sector polarity) and the solar radio flux (SRF) correlates with the north-south component of the electric field on the night-side. For more positive (sunward) $B_{x}$, or for greater SRF, the electric field is more southward/downward. However, strong mutual correlation between the IMF- $B_{x}$ and the SRF is found in the period analyzed (1987-1993), suggesting that the night-side correlation between electric fields and IMF- $B_{x}$ comes from the effect of the solar activity rather than the direct influence of the IMF- $B_{x}$. In fact it was also found from the data for almost two solar cycles that the IMF- $B_{x}$ (or $B_{y}$ ) dependence of the ionospheric foF 2 is very similar with the solar activity (sunspot number) dependence of it. This suggests that the mutual correlation between the solar activity and the IMF- $B_{x}$ (or $B_{y}$ ) causes the apparent correlation of the foF 2 with the IMF- $B_{x}$ which has been reported as a sector polarity effect.

On the other hand, the direct effects of the IMF- $B_{x}$ (or $B_{y}$ ) on the electric fields were also detected by taking the correlations between the time differentials of them and the results are consistent with the known IMF effects on the $S_{q}$ focus location. The differentials of the IMF- $B_{z}$ have significant correlation with the electric fields in limited local time zones and the sense of electric field is consistent with the penetration of the dawn-to-dusk electric field in the magnetosphere indicating the imperfect shielding by the plasmasphere.

\section{Introduction}

The interplanetary magnetic field (IMF) control on the magnetospheric plasma convection and on the polar ionospheric current systems are well established (e.g., Friss-Christensen et al., 1985 and references therein). The sector polarity effects on ionospheric foF2 have been reported (Potapova and Shapiro, 1974; Triskova, 1982; Bremer, 1988), and they were interpreted as an effect of the magnetospheric disturbance through the Russell-McPherron effect (Russell and McPherron, 1973; Bremer, 1988). However, the IMF effects on mid- or low-latitude ionosphere have not been well understood. Only the DP-2 type current fluctuations coherent with the IMF$B_{z}$ (Nishida, 1968) and the IMF sector polarity effect on the $S_{q}$ current system (Matsushita, 1975; Shiraki, 1975; Butcher, 1982) have been detected by ground magnetic field observations. On the contrary, there are many studies trying to relate the polar geomagnetic disturbances such as substorms with the ionospheric drift in mid- or low-latitudes (e.g., Blanc, 1983a; Ganguly et $a l ., 1987$ and references therein). However, the results are not conclusive to separate the IMF$B_{z}$ effects from the effects of the polar geomagnetic disturbances or thermospheric disturbances such as the neutral wind effects. In this paper, we have detected the real and apparent IMF effects in the ionospheric ion-drift data obtained by an incoherent scatter radar, the MU radar, at middle-latitude and those in the foF2 at middle and low-latitudes. 


\section{Data and Method of Analysis}

An incoherent scatter radar at Shigaraki $(34.85 \mathrm{~N}, 136.10 \mathrm{E})$ is a $46.5 \mathrm{MHz}$ Doppler radar with an active phased-array system (see Fukao et al., 1985) and has been operating since 1986. The electric field data were compiled from the raw data obtained in the standard ionospheric observation mode by a method described in Saryo et al. (1989) throughout the period analyzed in this paper. The ion-drift velocity vector was determined by integrating the echo in double pulse mode for 45 minutes to get one data point every one hour, and converted to the electric field vector orthogonal to the geomagnetic main field. The electric field vector has the meridional component $E_{s}$ (positive equatorward/downward) and the longitudinal component $E_{e}$ (positive eastward). The inclination of the geomagnetic field at the MU radar site is about 48 degrees and $L=1.25$.

The hourly electric field data were combined together with the hourly IMF data (in GSM coordinate system) obtained from the OMNI database at NASA/NSSDC (King, 1989), with geomagnetic indices, $D_{s t}$ (Sugiura and Kamei, 1991), $K_{p}$ (Mayaud, 1980), and ASY (Iyemori, 1990; Iyemori et al., 1992), with Kakioka hourly geomagnetic field data, and with the Ottawa $2800 \mathrm{MHz}$ solar radio flux (SRF) and international sunspot number (SSN) taken from the Solar Geophysical Data published by NOAA/NGDC. To check the geomagnetic disturbance effects on the ionosphere through the thermospheric circulation which would appear with some time delay, the ASY-H index for last 6 hours was averaged and added as a parameter. The period of the data set covers from October 1987 to December 1993, and the radar observation was made for about 48 hours almost every month. However, as the coverage of the IMF data is not continuous, only about half of the radar data were available for the correlation study with the IMF.

The correlations among those parameters were taken in the data sets which belong to each local time bin of 2 hours. The correlation between hourly parameters and 3 hourly or daily parameters is taken by using the 3 hourly or daily parameters at the hour. The number of data points for each local time bin of every 2 hours is around 100 samples after eliminating the bad data points as explained in the next paragraph.

A linear regression analysis was used with the estimation of statistical confidence level by calculating the correlation probability (Bevington, 1969). As the radar power is not strong enough to measure the ionospheric plasma drift with high accuracy, the estimated error for each data point is, in general, considerably large, that is, about $1 \mathrm{mV} / \mathrm{m}$ on the day-side and about $2 \mathrm{mV} / \mathrm{m}$ on the night-side. The magnitude of the electric field for most cases is less than $2 \mathrm{mV} / \mathrm{m}$ and more than $95 \%$ of the data have magnitude less than $5 \mathrm{mV} / \mathrm{m}$ even on the night-side. Therefore the data with estimated error greater than $2.5 \mathrm{mV} / \mathrm{m}$ or the data with magnitude greater than $5 \mathrm{mV} / \mathrm{m}$ were omitted from the analysis.

Table 1. The ionospheric station names and relevant parameters which are used to check the relationship between the IMF- $B_{x}$ or sunspot number and the foF 2 .

\begin{tabular}{llrrc}
\hline CODE & STATION & LAT & $E$-LONG & PERIOD \\
\hline AA343 & ALMA ATA & 43.2 & 76.9 & $1966-1989$ \\
TO535 & TOKYO & 35.7 & 139.5 & $1968-1989$ \\
MA720 & MAUI & 20.8 & 203.5 & $1966-1989$ \\
PA836 & POINT ARGUELLO & 35.6 & 239.4 & $1969-1989$ \\
WP937 & WALLOPS ISLAND & 37.9 & 284.3 & $1968-1987$ \\
SL051 & SLOUGH & 51.5 & 359.5 & $1967-1987$ \\
HU91K & HUANCAYO & -12.0 & 284.7 & $1966-1989$ \\
CB53N & CANBERRA & -35.3 & 149.0 & $1967-1988$ \\
\hline
\end{tabular}


The hourly foF2 data of the 6 stations in the period from 1966 to 1989 listed in Table 1 were taken from the database on the CD-ROM published by the NOAA/NGDC, and they were compared with the IMF and SSN data. The data periods covered by each foF2 station are not the same, and they are also listed in Table 1.

\section{Results}

\subsection{Mutual correlation among parameters}

Table 2 shows the correlation coefficients between each component of the ionospheric electric field or the SRF and that of the IMF. Table 3(a) and 3(b) list the correlation coefficients between the ionospheric electric fields $\left(E_{s}\right.$ and $\left.E_{e}\right)$ and geomagnetic activity indices $\left(K_{p}, D_{s t}\right.$ and ASY), magnetic field variation at Kakioka station (KAK), geomagnetic disturbance level of last 6 hours (6-hrs ASY-H) and solar radio flux (SRF). The $K_{p}$ index $(0,0+, 1-, 1, \ldots, 9-, 9)$ is converted to 28 levels $(0,1,2, \ldots, 27)$ for the correlation calculation. The geomagnetic disturbance fields at Kakioka station (KAK) were calculated by subtracting the average of the 5 international quiet days of the month for each component, $D$ (declination component in $\mathrm{nT}$ unit, positive eastward) and $H$ (horizontal component).

The number with parentheses under each correlation coefficient in these tables is the probability of correlation calculated assuming the normal distribution (Bevington, 1969). The coefficients

Table 2. The linear-correlation coefficients between the ionospheric electric field components, $E_{s}$ and $E_{e}$, and the IMF- $B_{x}, B_{y}$ and $B_{z}$ components. The correlation coefficients between the $2800 \mathrm{MHz}$ solar radio flux (SRF) and the IMF- $B_{x}$ or $B_{y}$ are also shown. $N$ denotes the number of data points. The cases with more than $95 \%$ correlation probability are underlined and those greater than $90 \%$ are with dashed lines. The averages of the absolute value of the correlation coefficients for all local time zones are also shown.

CORRELATION COEFFICIENTS

\begin{tabular}{|c|c|c|c|c|c|c|c|c|c|}
\hline \multirow[b]{2}{*}{ LT } & \multirow[b]{2}{*}{$\mathrm{N}$} & \multicolumn{3}{|c|}{ NU-Es(SOUTHWARD) } & \multicolumn{3}{|c|}{ MU-Ee(EASTTARD) } & \multicolumn{2}{|c|}{ SRF } \\
\hline & & $B X$ & BY & BZ & $\mathrm{BX}$ & $\mathrm{BY}$ & $\mathrm{BZ}$ & $B X$ & BY \\
\hline $0-2$ & 100 & $\frac{0.321}{(99.9)}$ & $\frac{-0.284}{(99.6)}$ & $\begin{array}{c}0.006 \\
(4.7)\end{array}$ & $\begin{array}{l}-0.075 \\
(54.2)\end{array}$ & $\begin{array}{r}0.098 \\
(66.8)\end{array}$ & $\frac{0.191}{(94.3)}$ & $\frac{0.544}{(99.9)}$ & $\frac{-0.356}{(99.9)}$ \\
\hline $2-4$ & 92 & $\begin{array}{r}0.018 \\
(13.5)\end{array}$ & $\begin{array}{r}0.148 \\
(84.1)\end{array}$ & $\begin{array}{r}0.170 \\
(89.5)\end{array}$ & $\begin{array}{c}-0.013 \\
(9.8)\end{array}$ & $\frac{0.276}{(99.2)}$ & $\begin{array}{l}-0.045 \\
(33.0)\end{array}$ & $\frac{0.432}{(99.9)}$ & $\frac{-0.319}{(99.7)}$ \\
\hline 4-6 & 80 & $\begin{array}{r}0.059 \\
(39.7)\end{array}$ & $\begin{array}{c}0.062 \\
(41.5)\end{array}$ & $\begin{array}{l}-0.099 \\
(61.8)\end{array}$ & $\begin{array}{l}-0.159 \\
(84.1)\end{array}$ & $\begin{array}{r}0.151 \\
(81.9)\end{array}$ & $\frac{-0.363}{(99.9)}$ & $\frac{0.354}{(99.9)}$ & $\frac{-0.240}{(96.7)}$ \\
\hline $6-8$ & 119 & $\begin{array}{r}0.126 \\
(82.8)\end{array}$ & $\begin{array}{r}0.080 \\
(61.3)\end{array}$ & $\begin{array}{r}0.082 \\
(62.5)\end{array}$ & $\begin{array}{c}-0.092 \\
(68.0)\end{array}$ & $\begin{array}{c}0.172 \\
(93.9)\end{array}$ & $\begin{array}{l}-0.019 \\
(16.3)\end{array}$ & $\frac{0.397}{(99.9)}$ & $\frac{-0.376}{(99.9)}$ \\
\hline $8-10$ & 114 & $\begin{array}{c}0.064 \\
(50.1)\end{array}$ & $\begin{array}{r}0.009 \\
(7.6)\end{array}$ & $\frac{0.214}{(97.8)}$ & $\begin{array}{c}-0.126 \\
(81.8)\end{array}$ & $\begin{array}{r}0.120 \\
(79.7)\end{array}$ & $\begin{array}{l}-0.129 \\
(82.9)\end{array}$ & $\frac{0.375}{(99.9)}$ & $\frac{-0.393}{(99.9)}$ \\
\hline $10-12$ & 108 & $\begin{array}{r}0.014 \\
(11.4)\end{array}$ & $\begin{array}{l}-0.016 \\
(13.1)\end{array}$ & $\frac{0.408}{(99.9)}$ & $\begin{array}{c}-0.090 \\
(64.6)\end{array}$ & $\begin{array}{l}-0.070 \\
(52.8)\end{array}$ & $\begin{array}{l}-0.103 \\
(71.1)\end{array}$ & $\frac{0.422}{(99.9)}$ & $\frac{-0.452}{(99.9)}$ \\
\hline $12-14$ & 117 & $\begin{array}{r}0.097 \\
(70.2)\end{array}$ & $\begin{array}{l}-0.139 \\
(86.5)\end{array}$ & $\begin{array}{r}0.038 \\
(31.6)\end{array}$ & $\begin{array}{c}-0.007 \\
(6.0)\end{array}$ & $\begin{array}{r}-0.173 \\
-(93.8)\end{array}$ & $\begin{array}{l}-0.089 \\
(66.0)\end{array}$ & $\frac{0.411}{(99.9)}$ & $\frac{-0.427}{(99.9)}$ \\
\hline $14-16$ & 104 & $\begin{array}{r}0.027 \\
(21.4)\end{array}$ & $\begin{array}{r}0.017 \\
(13.6)\end{array}$ & $\begin{array}{l}-0.070 \\
(52.0)\end{array}$ & $\begin{array}{c}-0.002 \\
(1.6)\end{array}$ & $\begin{array}{r}0.001 \\
(0.8)\end{array}$ & $\begin{array}{c}0.074 \\
(54.5)\end{array}$ & $\frac{0.332}{(99.9)}$ & $\frac{-0.470}{(99.9)}$ \\
\hline $16-18$ & 121 & $\frac{0.363}{(99.9)}$ & $\begin{array}{l}-0.150 \\
(89.9)\end{array}$ & $\frac{0.217}{(98.3)}$ & $\begin{array}{l}-0.107 \\
(75.7)\end{array}$ & $\frac{0.207}{(97.7)}$ & $\frac{-0.364}{(99.9)}$ & $\frac{0.290}{(99.8)}$ & $\frac{-0.444}{(99.9)}$ \\
\hline $18-20$ & 127 & $\frac{0.353}{(99.9)}$ & $\frac{-0.208}{(98.1)}$ & $\begin{array}{c}0.108 \\
(77.3)\end{array}$ & $\frac{-0.215}{(98.5)}$ & $\begin{array}{r}0.123 \\
(83.2)\end{array}$ & $\frac{-0.226}{(98.9)}$ & $\frac{0.476}{(99.9)}$ & $\frac{-0.456}{(99.9)}$ \\
\hline $20-22$ & 115 & $\frac{0.262}{(99.5)}$ & $\frac{-0.256}{(99.4)}$ & $\begin{array}{r}0.144 \\
(87.5)\end{array}$ & $\begin{array}{c}-0.064 \\
(50.3)\end{array}$ & $\begin{array}{l}-0.025 \\
(20.9)\end{array}$ & $\begin{array}{c}0.054 \\
(43.3)\end{array}$ & $\frac{0.472}{(99.9)}$ & $\frac{-0.483}{(99.9)}$ \\
\hline $22-24$ & 100 & $\frac{0.327}{(99.9)}$ & $\frac{-0.241}{(98.4)}$ & $\begin{array}{l}-0.125 \\
(78.5)\end{array}$ & $\begin{array}{l}-0.152 \\
(86.9)\end{array}$ & $\begin{array}{r}0.105 \\
(70.2)\end{array}$ & $\frac{0.209}{(96.3)}$ & $\frac{0.496}{(99.9)}$ & $\frac{-0.385}{(99.9)}$ \\
\hline MEAN & 108 & 0.169 & 0.134 & 0.140 & 0.092 & 0.127 & 0.155 & 0.417 & 0.400 \\
\hline
\end{tabular}


Table 3. The correlation coefficients of the electric field components, $E_{s}$ and $E_{e}$, with various geomagnetic disturbance indices and a solar activity index. (a) is for the $E_{s}$ and (b) is for the $E_{e}$ component. $N$ indicates the number of data points.

(a)

\begin{tabular}{|c|c|c|c|c|c|c|c|c|c|}
\hline \multirow[b]{2}{*}{ LT } & \multirow[b]{2}{*}{$\mathrm{N}$} & \multicolumn{3}{|c|}{ WU-Es(SOUTHWARD) } & \multirow[b]{2}{*}{ ASY-H } & \multirow[b]{2}{*}{ KAK-D } & \multirow[b]{2}{*}{ KAK-H } & \multirow{2}{*}{$\begin{array}{c}\text { 6-HRS } \\
\text { ASY-H }\end{array}$} & \multirow[b]{2}{*}{ SRP } \\
\hline & & KP & DST & ASY-D & & & & & \\
\hline $0-2$ & 152 & $\begin{array}{l}-0.122 \\
(86.6)\end{array}$ & $\frac{0.144}{(92.3)}$ & $\begin{array}{r}0.037 \\
(34.9)\end{array}$ & $\begin{array}{l}-0.036 \\
(34.0)\end{array}$ & $\begin{array}{l}-0.021 \\
(20.3)\end{array}$ & $\frac{0.138}{(91.0)}$ & $\begin{array}{l}-0.130 \\
(89.0)\end{array}$ & $\frac{0.310}{(99.9)}$ \\
\hline $2-4$ & 148 & $\begin{array}{l}-0.129 \\
(88.2)\end{array}$ & $\begin{array}{r}0.100 \\
(77.3)\end{array}$ & $\begin{array}{r}0.042 \\
(38.8)\end{array}$ & $\begin{array}{r}-0.156 \\
-94.2)\end{array}$ & $\begin{array}{r}0.011 \\
(10.6)\end{array}$ & $\begin{array}{r}0.095 \\
(74.9)\end{array}$ & $\begin{array}{l}-0.121 \\
(85.70\end{array}$ & $\begin{array}{l}0.135 \\
(89.8)\end{array}$ \\
\hline 4-6 & 144 & $\begin{array}{r}0.093 \\
(73.2)\end{array}$ & $\begin{array}{r}0.150 \\
(92.7)\end{array}$ & $\begin{array}{l}-0.078 \\
(64.7)\end{array}$ & $\begin{array}{l}-0.037 \\
(34.0)\end{array}$ & $\begin{array}{l}-0.103 \\
(78.1)\end{array}$ & $\frac{0.166}{(95.3)}$ & $\begin{array}{l}-0.086 \\
(69.5)\end{array}$ & $\begin{array}{l}0.028 \\
(26.1)\end{array}$ \\
\hline $6-8$ & 204 & $\frac{-0.197}{(99.5)}$ & $\frac{0.174}{(98.7)}$ & $\begin{array}{l}-0.105 \\
(86.5)\end{array}$ & $\frac{-0.224}{(99.9)}$ & $\begin{array}{l}-0.036 \\
(39.1)\end{array}$ & $\frac{0.246}{(99.9)}$ & $\frac{-0.252}{(99.9)}$ & $\begin{array}{l}0.050 \\
(52.2)\end{array}$ \\
\hline $8-10$ & 210 & $\frac{-0.318}{(99.9)}$ & $\begin{array}{c}0.103 \\
(86.3)\end{array}$ & $\begin{array}{r}-0.124 \\
(92.7)\end{array}$ & $\frac{-0.161}{(98.0)}$ & $\frac{0.166}{(98.4)}$ & $\begin{array}{c}0.042 \\
(45.5)\end{array}$ & $\frac{-0.218}{(99.9)}$ & $\begin{array}{l}0.098 \\
(84.3)\end{array}$ \\
\hline $10-12$ & 224 & $\frac{-0.282}{(99.9)}$ & $\begin{array}{r}0.100 \\
(86.4)\end{array}$ & $\frac{-0.116}{(91.7)}$ & $\frac{-0.196}{(99.7)}$ & $\begin{array}{r}0.127 \\
(94.2)\end{array}$ & $\begin{array}{l}-0.026 \\
(30.1)\end{array}$ & $\frac{-0.180}{(99.3)}$ & $\begin{array}{c}-0.120 \\
-(92.7)\end{array}$ \\
\hline $12-14$ & 229 & $\begin{array}{l}-0.018 \\
(21.4)\end{array}$ & $\begin{array}{r}0.115 \\
(91.8) \\
(91.8)\end{array}$ & $\begin{array}{l}-0.051 \\
(55.8)\end{array}$ & $\begin{array}{l}-0.043 \\
(48.3)\end{array}$ & $\frac{0.121}{(93.2)}$ & $\begin{array}{r}0.037 \\
(42.2)\end{array}$ & $\begin{array}{c}-0.109 \\
(90.0)\end{array}$ & $\frac{-0.131}{(95.2)}$ \\
\hline $14-16$ & 213 & $\begin{array}{l}-0.096 \\
(83.7)\end{array}$ & $\frac{0.140}{(95.9)}$ & $\begin{array}{c}-0.011 \\
(12.7)\end{array}$ & $\frac{-0.152}{(97.3)}$ & $\begin{array}{r}0.056 \\
(58.4)\end{array}$ & $\frac{0.158}{(97.9)}$ & $\begin{array}{l}-0.056 \\
(58.4)\end{array}$ & $\frac{-0.118}{(91.4)}$ \\
\hline $16-18$ & 220 & $\frac{-0.135}{(95.5)}$ & $\begin{array}{r}0.056 \\
(59.1)\end{array}$ & $\begin{array}{l}-0.057 \\
(60.0)\end{array}$ & $\begin{array}{c}-0.076 \\
(73.8)\end{array}$ & $\begin{array}{r}0.066 \\
(67.0)\end{array}$ & $\frac{0.139}{(96.1)}$ & $\frac{-0.113}{(90.5)}$ & $\frac{0.118}{(91.9)}$ \\
\hline $18-20$ & 230 & $\frac{-0.198}{(99.7)}$ & $\begin{array}{l}-0.021 \\
(24.9)\end{array}$ & $\begin{array}{l}-0.092 \\
(83.6)\end{array}$ & $\begin{array}{l}-0.114 \\
(91.5)\end{array}$ & $\begin{array}{l}-0.041 \\
(46.4)\end{array}$ & $\begin{array}{r}0.118 \\
(92.6)\end{array}$ & $\begin{array}{l}-0.064 \\
(66.6)\end{array}$ & $\frac{0.276}{(99.9)}$ \\
\hline 20 & 194 & $\begin{array}{l}-0.036 \\
(38.2)\end{array}$ & $\begin{array}{l}-0.104 \\
(85.1)\end{array}$ & $\begin{array}{l}-0.078 \\
(72.0)\end{array}$ & $\begin{array}{c}0.054 \\
(54.5)\end{array}$ & $\frac{-0.150}{(96.3)}$ & $\begin{array}{c}0.012 \\
(13.2)\end{array}$ & $\begin{array}{c}-0.003 \\
(3.3)\end{array}$ & $\frac{0.457}{(99.9)}$ \\
\hline $22-24$ & 155 & $\begin{array}{l}-0.082 \\
(69.0)\end{array}$ & $\begin{array}{c}0.026 \\
(25.2)\end{array}$ & $\begin{array}{l}-0.055 \\
(50.3)\end{array}$ & $\begin{array}{r}0.076 \\
(65.3)\end{array}$ & $\begin{array}{r}0.030 \\
(28.9)\end{array}$ & $\begin{array}{r}0.121 \\
(86.6)\end{array}$ & $\begin{array}{l}-0.052 \\
(48.0)\end{array}$ & $\frac{0.474}{(99.9)}$ \\
\hline MEAN & 194 & 0.142 & 0.103 & 0.070 & 0.110 & 0.077 & 0.108 & 0.115 & 0.193 \\
\hline
\end{tabular}

with underline indicate the combination where the probability of 'not' un-correlated is greater than $95 \%$ and those underlined with dashed lines indicate that greater than $90 \%$. It is noticed that the correlation coefficients (or probabilities) of the $E_{s}$ component with the IMF- $B_{x}$ and/or the SRF are significantly high on the night-side. The probability of correlation is higher than $99 \%$ for such cases as 18-20 LT, 20-22 LT, 22-24 LT and 0-2 LT. The IMF- $B_{y}$ also shows significant level of correlation probability though it is not so good as for the cases of the IMF- $B_{x}$ nor the $\mathrm{SRF}$. The correlation with the IMF- $B_{z}$ is high at some local time zones such as 10-12 LT for the $E_{s}$ and 4-6, 16-18, and 22-02 LT for the $E_{e}$ component.

In general, the correlation coefficients of the electric fields with geomagnetic indices on the night side (see Table $3(\mathrm{a})$ and $3(\mathrm{~b})$ ) are lower than those with the IMF- $B_{x}$ or with the SRF, and the local time dependence of correlation is similar with that of the IMF- $B_{z}$ in Table 2. This similarity is reasonable because of the strong IMF- $B_{z}$ dependence of the geomagnetic activity.

A clear correlation is seen between the IMF- $B_{x}$ (or IMF- $B_{y}$ ) and the SRF for the data period of radar observation (see Table 2). The average correlation coefficient is about 0.4 and correlation probability is more than $99 \%$ for all local times. Note that these two parameters, of course, should not have any local time dependence because both of them are not controlled by Earth's rotation but the sun, and the apparent dependence probably comes from statistical deviation, because each of the data sets is not large enough to give a constant correlation coefficient. 
Table 3. (continued).

(b)

CORRELATION COEFFICIENTS

\begin{tabular}{|c|c|c|c|c|c|c|c|c|c|}
\hline \multirow[b]{2}{*}{ LT } & \multirow[b]{2}{*}{ 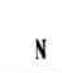 } & \multicolumn{3}{|c|}{ VU-Ee(EASTTARD) } & \multirow[b]{2}{*}{ ASY-H } & \multirow[b]{2}{*}{ KAK-D } & \multicolumn{3}{|c|}{ 6-HRS } \\
\hline & & KP & DST & ASY-D & & & KAK-H & ASY-H & SRF \\
\hline $0-2$ & 152 & $\begin{array}{l}-0.029 \\
(27.7)\end{array}$ & $\begin{array}{r}0.021 \\
(20.3)\end{array}$ & $\begin{array}{r}0.005 \\
(4.9)\end{array}$ & $\begin{array}{l}-0.023 \\
(22.1)\end{array}$ & $\begin{array}{r}0.005 \\
(4.9)\end{array}$ & $\begin{array}{l}-0.038 \\
(35.8)\end{array}$ & $\begin{array}{c}-0.003 \\
(2.9)\end{array}$ & $\begin{array}{r}0.050 \\
(45.9)\end{array}$ \\
\hline $2-4$ & 148 & $\begin{array}{l}-0.076 \\
(64.1)\end{array}$ & $\begin{array}{l}-0.025 \\
(23.7)\end{array}$ & $\begin{array}{c}0.086 \\
(70.1)\end{array}$ & $\begin{array}{c}0.013 \\
(12.5)\end{array}$ & $\begin{array}{r}0.030 \\
(28.3)\end{array}$ & $\begin{array}{r}0.057 \\
(50.9)\end{array}$ & $\begin{array}{l}-0.016 \\
(15.3)\end{array}$ & $\begin{array}{r}0.041 \\
(37.9)\end{array}$ \\
\hline 4-6 & 144 & $\begin{array}{r}0.107 \\
(79.8)\end{array}$ & $\frac{-0.309}{(99.9)}$ & $\frac{0.296}{(99.9)}$ & $\begin{array}{l}0.111 \\
(81.5)\end{array}$ & $\begin{array}{r}0.090 \\
(71.7)\end{array}$ & $\frac{-0.226}{(99.4)}$ & $\begin{array}{r}0.106 \\
(79.4)\end{array}$ & $\begin{array}{r}0.049 \\
(44.0)\end{array}$ \\
\hline $6-8$ & 204 & $\frac{-0.227}{(99.9)}$ & $\begin{array}{r}0.099 \\
(84.1)\end{array}$ & $\begin{array}{l}-0.093 \\
(81.4)\end{array}$ & $\frac{-0.229}{(99.9)}$ & $\frac{-0.156}{(97.4)}$ & $\begin{array}{l}-0.028 \\
(30.9)\end{array}$ & $\frac{-0.183}{(99.1)}$ & $\begin{array}{l}-0.024 \\
(26.7)\end{array}$ \\
\hline $8-10$ & 210 & $\begin{array}{r}0.002 \\
(2.3)\end{array}$ & $\begin{array}{l}-0.084 \\
(77.5)\end{array}$ & $\begin{array}{r}0.091 \\
(81.1)\end{array}$ & $\begin{array}{l}-0.005 \\
(5.7)\end{array}$ & $\begin{array}{l}-0.050 \\
(52.9)\end{array}$ & $\frac{-0.120}{(91.7)}$ & $\begin{array}{r}0.040 \\
(43.6)\end{array}$ & $\begin{array}{r}0.082 \\
(76.3)\end{array}$ \\
\hline $10-12$ & 224 & $\begin{array}{r}0.050 \\
(54.3)\end{array}$ & $\frac{-0.119}{(92.4)}$ & $\begin{array}{r}0.040 \\
(44.9)\end{array}$ & $\begin{array}{r}0.076 \\
(74.3)\end{array}$ & $\begin{array}{r}0.097 \\
(85.2)\end{array}$ & $\begin{array}{l}-0.103 \\
(87.6)\end{array}$ & $\begin{array}{r}0.100 \\
(86.4)\end{array}$ & $\begin{array}{l}-0.004 \\
(4.7)\end{array}$ \\
\hline $12-14$ & 229 & $\begin{array}{r}0.101 \\
(87.2)\end{array}$ & $\begin{array}{r}0.012 \\
(14.3)\end{array}$ & $\begin{array}{r}0.018 \\
(21.4)\end{array}$ & $\begin{array}{l}-0.031 \\
(35.9)\end{array}$ & $\begin{array}{r}0.099 \\
(86.5)\end{array}$ & $\begin{array}{l}-0.048 \\
(53.0)\end{array}$ & $\begin{array}{r}0.001 \\
(1.2)\end{array}$ & $\begin{array}{l}-0.054 \\
(58.4)\end{array}$ \\
\hline 14 & 213 & $\begin{array}{l}-0.024 \\
(27.2)\end{array}$ & $\begin{array}{r}0.049 \\
(52.3)\end{array}$ & $\begin{array}{l}-0.028 \\
(31.5)\end{array}$ & $\begin{array}{l}-0.111 \\
(89.4)\end{array}$ & $\begin{array}{r}0.118 \\
(91.4)\end{array}$ & $\begin{array}{r}0.019 \\
(21.7)\end{array}$ & $\frac{-0.164}{(98.3)}$ & $\begin{array}{l}-0.019 \\
(21.7)\end{array}$ \\
\hline $16-18$ & 220 & $\begin{array}{l}-0.047 \\
(51.2)\end{array}$ & $\begin{array}{l}-0.075 \\
(73.2)\end{array}$ & $\frac{0.188}{(99.5)}$ & $\begin{array}{r}-0.006 \\
(7.1)\end{array}$ & $\begin{array}{l}-0.037 \\
(41.5)\end{array}$ & $\begin{array}{l}-0.041 \\
(45.5)\end{array}$ & $\begin{array}{l}-0.094 \\
(83.5)\end{array}$ & $\begin{array}{l}-0.037 \\
(41.5)\end{array}$ \\
\hline $18-20$ & 230 & $\begin{array}{l}-0.041 \\
(46.4)\end{array}$ & $\begin{array}{r}0.015 \\
(17.9)\end{array}$ & $\begin{array}{r}0.057 \\
(61.0)\end{array}$ & $\begin{array}{r}-0.003 \\
(3.6)\end{array}$ & $\begin{array}{l}-0.011 \\
(13.2)\end{array}$ & $\begin{array}{l}-0.036 \\
(41.3)\end{array}$ & $\begin{array}{l}-0.075 \\
(74.3)\end{array}$ & $\begin{array}{r}0.014 \\
(16.7)\end{array}$ \\
\hline $20-22$ & 194 & $\begin{array}{r}0.025 \\
(27.1)\end{array}$ & $\begin{array}{l}-0.007 \\
(7.7)\end{array}$ & $\begin{array}{r}0.016 \\
(17.5)\end{array}$ & $\begin{array}{r}0.117 \\
(89.6)\end{array}$ & $\begin{array}{r}0.053 \\
(53.7)\end{array}$ & $\begin{array}{l}-0.020 \\
(21.8)\end{array}$ & $\begin{array}{r}0.086 \\
(76.7)\end{array}$ & $\begin{array}{r}0.066 \\
(63.9)\end{array}$ \\
\hline $22-24$ & 155 & $\begin{array}{l}-0.018 \\
(17.6)\end{array}$ & $\begin{array}{l}-0.012 \\
(11.8)\end{array}$ & $\frac{0.180}{(97.5)}$ & $\begin{array}{r}0.128 \\
(88.8)\end{array}$ & $\begin{array}{l}-0.071 \\
(62.0)\end{array}$ & $\begin{array}{l}-0.005 \\
(4.9)\end{array}$ & $\begin{array}{l}-0.034 \\
(32.6)\end{array}$ & $\begin{array}{r}0.026 \\
(25.2)\end{array}$ \\
\hline MEAN & 194 & 0.062 & 0.069 & 0.091 & 0.071 & 0.068 & 0.062 & 0.075 & 039 \\
\hline
\end{tabular}

\subsection{Correlation between temporal variations}

To separate the effects of the IMF on the electric fields from those of the solar activity, the differentials between successive hours, that is, the difference between the hour and one hour before, are taken for both the MU radar data and the IMF data. The differential was not taken if a data gap exists between two data points and such points were omitted from analysis. By taking the differentials, we can avoid the effects of solar activity which is given as a daily solar index SRF or SSN, because the phenomena on the solar surface should not have any correlation with the temporal variation of the IMF at the Earth's orbit with time scale of one hour. We calculated the linear regression coefficients as well as the correlation coefficients between the differentials of ionospheric electric field and that of each IMF component.

Table 4(a), (b) and (c) show the results for IMF- $B_{x}, B_{y}$ and $B_{z}$, respectively. The cases where the correlation probability is higher than $90 \%$ are underlined and those higher than $80 \%$ is underlined by dashed lines. The night-side high correlation between IMF- $B_{x}$ and $E_{s}$ such as seen in Table 2 is not seen anymore. This shows that the high correlation in Table 2 is apparent and comes from the mutual correlation between the solar activity and IMF polarity. There are, however, some local times when the differentials of the IMF correlate with those of the ionospheric electric field. That is, the IMF- $B_{y}$ shows significant correlation with the north-south component of the electric field on the dayside (08-14 LT), and the IMF- $B_{z}$ with that on the evening side and in the early morning sector. In general, the correlation with the $E_{e}$ component is weak for these parameters except for the IMF- $B_{z}$ in midnight region.

Figures 1(a) and 1(b) show the local time dependence of the IMF- $B_{x}$ effects on the foF 2 at 
Table 4. The linear correlation coefficients between the differentials of the hourly IMF and those of the electric fields. $N$ denotes the number of samples. (a), (b) and (c) are for the IMF- $B_{x}, B_{y}$ and $B_{z}$, respectively. The cases with more than $90 \%$ correlation probability are underlined and those greater than $80 \%$ are with dashed lines.

(a) IMF- Bx

\begin{tabular}{|c|c|c|c|c|c|c|c|}
\hline \multirow[b]{2}{*}{ LT } & \multicolumn{4}{|c|}{$\delta \mathrm{Es}=\mathrm{A} 1 * \delta \mathrm{Bx}+\mathrm{B} 1$} & \multicolumn{3}{|c|}{$\delta \mathrm{Ee}=\mathrm{A} 2 * \delta \mathrm{Bx}+\mathrm{B} 2$} \\
\hline & N & $\mathbf{R}$ & $A 1$ & B1 & $\mathbf{R}$ & A2 & B2 \\
\hline $00-02$ & 41 & $\begin{array}{c}0.08 \\
(38.1)\end{array}$ & 0.03 & -0.05 & $\begin{array}{l}-0.03 \\
(14.8)\end{array}$ & -0.01 & 0.14 \\
\hline $02-04$ & 80 & $\begin{array}{c}-0.15 \\
(81.6)\end{array}$ & -0.02 & -0.25 & $\begin{array}{c}0.08 \\
(51.9)\end{array}$ & 0.04 & 0.12 \\
\hline $04-06$ & 67 & $\begin{array}{c}-0.03 \\
(19.0)\end{array}$ & -0.01 & -0.42 & $\begin{array}{c}0.02 \\
(12.8)\end{array}$ & 0.01 & -0.07 \\
\hline $06-08$ & 106 & $\begin{array}{l}-0.08 \\
(58.5)\end{array}$ & -0.03 & 0.03 & $\begin{array}{c}-0.01 \\
(8.1)\end{array}$ & -0.01 & 0.10 \\
\hline $08-10$ & 50 & $\begin{array}{l}-0.03 \\
(16.4)\end{array}$ & -0.01 & -0.06 & $\begin{array}{l}-0.04 \\
(21.7)\end{array}$ & -0.01 & 0.20 \\
\hline $10-12$ & 91 & $\begin{array}{c}0.10 \\
(65.4)\end{array}$ & 0.03 & -0.08 & $\begin{array}{c}0.08 \\
(54.9)\end{array}$ & 0.03 & -0.07 \\
\hline $12-14$ & 86 & $\frac{0.14}{(80.1)}$ & 0.05 & -0.05 & $\begin{array}{l}-0.02 \\
(14.5)\end{array}$ & -0.01 & -0.36 \\
\hline $14-16$ & 87 & $\frac{0.17}{(88.5)}$ & 0.07 & 0.09 & $\begin{array}{l}-0.10 \\
(34.3)\end{array}$ & -0.05 & 0.00 \\
\hline $16-18$ & 95 & $\frac{0.19}{(93.5)}$ & 0.06 & 0.41 & $\begin{array}{c}0.12 \\
(75.3)\end{array}$ & 0.04 & 0.07 \\
\hline $18-20$ & 113 & $\begin{array}{l}0.00 \\
(0.0)\end{array}$ & 0.00 & 0.41 & $\begin{array}{c}0.03 \\
(24.8)\end{array}$ & 0.01 & -0.10 \\
\hline $20-22$ & 107 & $\begin{array}{l}-0.08 \\
(58.7)\end{array}$ & -0.03 & 0.09 & $\begin{array}{l}-0.02 \\
(16.2)\end{array}$ & -0.01 & -0.11 \\
\hline $22-24$ & 92 & $\begin{array}{c}0.04 \\
(29.5)\end{array}$ & 0.01 & -0.06 & $\begin{array}{c}0.01 \\
(7.5)\end{array}$ & 0.00 & 0.09 \\
\hline MEAN & 85 & 0.091 & & & 0.047 & & \\
\hline
\end{tabular}

each station, where the differences in foF2 between toward (IMF- $B_{x}>5 \mathrm{nT}$ ) and away (IMF$B_{x}<-5 \mathrm{nT}$ ) polarities respectively are plotted for vernal (i.e., February-April) and autumnal (August-October) equinoxes. The criterion for IMF-Bx $\left(\left|B_{x}\right|>5 \mathrm{nT}\right.$ ) is to select the periods having clear IMF polarity. To avoid the geomagnetic storm effects on the foF2 in the analysis, the cases where the average $a p$ index (see Mayaud, 1980) of last 6 hours are greater than 15 were omitted, and the average $a p$ and SSN values for IMF- $B_{x}>5 \mathrm{nT}$ (up) and $<-5 \mathrm{nT}$ (down) are shown on the right-side of each plots. The data points which satisfy the above conditions distribute rather uniformly during the two solar cycles.

To demonstrate the mutual correlation between the IMF and solar activity, the existence of bias for SSN in the data set divided to 2 hours local time bins was examined. Figures 2(a) and 2(b) show the 'local time dependence' of the solar activity at each station where the differences in the SSN between the cases of $B_{x}>5 \mathrm{nT}$ and $B_{x}<-5 \mathrm{nT}$ are presented for vernal and autumnal equinoxes. An error bar indicates the square-root sum of the standard error for the two conditions (i.e., $B_{x}>5 \mathrm{nT}$ and $B_{x}<-5 \mathrm{nT}$ ), and the standard error is defined as the standard deviation divided by the square-root of the number of samples at each local time which was around 200 in our case. Since the solar activity and the earth's rotation (i.e., the local time) should be independent each other, the 'local time dependence' of the solar activity is an apparent result caused by insufficient number of the data point. It should be noted that the lines would be straight (i.e., no local time dependence) and on the zero level if there is no correlation between 
Table 4. (continued).

(b) IIIF-By

\begin{tabular}{|c|c|c|c|c|c|c|c|}
\hline \multirow[b]{2}{*}{ LT } & \multicolumn{4}{|c|}{$\delta \mathrm{Es}=\mathrm{A} 1 * \delta \mathrm{Bx}+\mathrm{B} 1$} & \multicolumn{3}{|c|}{$\delta \mathrm{Ee}=\mathrm{A} 2 * \delta \mathrm{By}+\mathrm{B} 2$} \\
\hline & N & $\mathbf{R}$ & $A 1$ & B1 & $\mathbf{R}$ & A2 & B2 \\
\hline $00-02$ & 41 & $\begin{array}{l}-0.15 \\
(65.1)\end{array}$ & -0.06 & -0.05 & $\begin{array}{c}0.12 \\
(54.5)\end{array}$ & 0.05 & 0.14 \\
\hline $02-04$ & 80 & $\begin{array}{c}0.03 \\
(20.8)\end{array}$ & 0.01 & -0.26 & $\begin{array}{l}-0.10 \\
(62.3)\end{array}$ & -0.05 & 0.12 \\
\hline $04-06$ & 67 & $\begin{array}{l}-0.01 \\
(6.4)\end{array}$ & 0.00 & -0.42 & $\begin{array}{c}0.00 \\
(0.0)\end{array}$ & 0.00 & -0.07 \\
\hline $06-08$ & 106 & $\begin{array}{c}0.10 \\
(69.2)\end{array}$ & 0.03 & 0.02 & $\frac{0.16}{(89.9)}$ & 0.09 & 0.09 \\
\hline $08-10$ & 50 & $\frac{0.21}{(85.7)}$ & 0.10 & -0.05 & $\begin{array}{l}-0.09 \\
(46.6)\end{array}$ & -0.03 & 0.20 \\
\hline $10-12$ & 91 & $\frac{0.19}{(92.9)}$ & 0.05 & -0.09 & $\begin{array}{l}-0.01 \\
(7.5)\end{array}$ & 0.00 & -0.06 \\
\hline $12-14$ & 86 & $\frac{0.19}{(92.0)}$ & 0.06 & -0.06 & $\begin{array}{l}-0.02 \\
(14.5)\end{array}$ & -0.01 & -0.35 \\
\hline $14-16$ & 87 & $\begin{array}{l}-0.07 \\
(48.1)\end{array}$ & -0.02 & 0.08 & $\begin{array}{l}-0.09 \\
(59.3)\end{array}$ & -0.02 & 0.00 \\
\hline $16-18$ & 95 & $\begin{array}{c}0.05 \\
(37.0)\end{array}$ & 0.01 & 0.42 & $\begin{array}{c}0.02 \\
(15.3)\end{array}$ & 0.01 & 0.08 \\
\hline $18-20$ & 113 & $\begin{array}{l}-0.08 \\
(60.0)\end{array}$ & -0.02 & 0.41 & $\begin{array}{c}0.12 \\
(79.4)\end{array}$ & 0.04 & -0.10 \\
\hline $20-22$ & 107 & $\begin{array}{l}-0.14 \\
(85.0)\end{array}$ & -0.05 & 0.08 & $\begin{array}{l}-0.08 \\
(58.7)\end{array}$ & -0.04 & -0.12 \\
\hline $22-24$ & 92 & $\begin{array}{l}-0.14 \\
(81.7)\end{array}$ & -0.04 & -0.06 & $\begin{array}{c}0.01 \\
(7.5)\end{array}$ & 0.00 & 0.09 \\
\hline MEAN & 85 & 0.113 & & & 0.068 & & \\
\hline
\end{tabular}

the IMF- $B_{x}$ and the SSN.

\section{Discussion}

\subsection{Solar activity effects}

It is well known that the solar activity influences very strongly the condition of the ionosphere and hence it is expected that the ionospheric electric fields also have the solar activity dependence (e.g., Oliver et al., 1993). The existence of significant correlation between the IMF- $B_{x}$ (or $B_{y}$ ) and the solar activity index SRF is reasonable if the data period is not long enough, for example, less than several months, because the coronal hole or other large scale structures on the solar surface determine the IMF structure and such solar surface condition affects to the daily solar index, but such correlation will be smoothed out if the period is long enough. However, in the present case, the IMF and solar activity still show the mutual correlation though the data period used in this study spans 7 years.

Therefore most of the night-side IMF- $B_{x}$ (or $B_{y}$ ) effects on the electric fields in Table 2 are the apparent correlation caused by the mutual correlation between the IMF structure and the solar activity. The sense of the night-side correlation between the $E_{s}$ and the SRF (Table 3(a)) is consistent with the solar activity dependence of the eastward ion-drift velocity reported by Oliver et al. (1993). The mechanism which causes the mutual correlation is beyond the scope of this paper, but we should be careful about this mutual correlation when we make similar statistical study with IMF or solar activity even if we use the data for more than several years. 
Table 4. (continued).

(c) INF-Bz

\begin{tabular}{|c|c|c|c|c|c|c|c|}
\hline \multirow[b]{2}{*}{$\mathrm{LT}$} & \multirow[b]{2}{*}{$\mathrm{N}$} & \multicolumn{3}{|c|}{$\delta \mathrm{Es}=\mathrm{A} 1 * \delta \mathrm{Bz}+\mathrm{B} 1$} & \multicolumn{3}{|c|}{$\delta \mathrm{Ee}=\mathrm{A} 2 * \delta \mathrm{B} 2+\mathrm{B} 2$} \\
\hline & & $\mathbf{R}$ & $\mathrm{Al}$ & BI & $\mathbf{R}$ & A2 & B2 \\
\hline $00-02$ & 41 & $\begin{array}{l}-0.26 \\
(89.9)\end{array}$ & -0.08 & -0.06 & $\frac{0.42}{(99.4)}$ & 0.12 & 0.16 \\
\hline 02-04 & 80 & $\begin{array}{c}0.12 \\
(71.1)\end{array}$ & 0.05 & -0.25 & $\begin{array}{c}0.11 \\
(66.9)\end{array}$ & 0.06 & 0.12 \\
\hline $04-06$ & 67 & $\frac{-0.25}{(95.9)}$ & -0.09 & -0.40 & $\begin{array}{c}0.07 \\
(42.6)\end{array}$ & 0.03 & -0.08 \\
\hline $06-08$ & 106 & $\begin{array}{c}0.01 \\
(8.1)\end{array}$ & 0.00 & 0.02 & $\begin{array}{c}0.02 \\
(16.1)\end{array}$ & 0.01 & 0.09 \\
\hline $08-10$ & 50 & $\begin{array}{c}0.10 \\
(51.0)\end{array}$ & 0.04 & -0.03 & $\begin{array}{c}0.00 \\
(0.0)\end{array}$ & 0.00 & 0.21 \\
\hline $10-12$ & 91 & $\begin{array}{c}0.10 \\
(65.4)\end{array}$ & 0.02 & -0.07 & $\begin{array}{l}-0.01 \\
(7.5)\end{array}$ & 0.00 & -0.06 \\
\hline $12-14$ & 86 & $\begin{array}{c}0.01 \\
(7.3)\end{array}$ & 0.00 & -0.06 & $\begin{array}{l}-0.05 \\
(35.2)\end{array}$ & -0.01 & -0.35 \\
\hline $14-16$ & 87 & $\frac{0.18}{(90.5)}$ & 0.05 & 0.10 & $\begin{array}{c}0.12 \\
(73.2)\end{array}$ & 0.04 & 0.02 \\
\hline $16-18$ & 95 & $\frac{0.18}{(91.9)}$ & 0.05 & 0.43 & $\begin{array}{c}0.10 \\
(66.5)\end{array}$ & 0.03 & 0.08 \\
\hline $18-20$ & 113 & $\frac{0.22}{(98.1)}$ & 0.04 & 0.42 & $\begin{array}{l}-0.03 \\
(24.8)\end{array}$ & -0.01 & -0.10 \\
\hline $20-22$ & 107 & $\begin{array}{l}-0.05 \\
(39.1)\end{array}$ & -0.01 & 0.09 & $\begin{array}{l}-0.08 \\
(58.7)\end{array}$ & -0.02 & -0.11 \\
\hline $22-24$ & 92 & $\begin{array}{c}0.05 \\
(36.4)\end{array}$ & 0.01 & -0.06 & $\begin{array}{c}0.14 \\
(81.7)\end{array}$ & 0.04 & 0.11 \\
\hline NEAN & 85 & 0.127 & & & 0.000 & & \\
\hline
\end{tabular}

The IMF sector effects on the foF2 (Potapova and Shapiro, 1974; Triskova, 1982; Bremer, 1988), which have been explained as the geomagnetic disturbance effect caused by the southward IMF modulated by the Russell-McPherron effect, could also be explained by the mutual correlation. To check this possibility, the correlation of the foF 2 with the IMF and sunspot number (SSN) are examined using the data for about 22 years.

We see a striking similarity in the local time dependence between Figs. 1(a) and 2(a) and between Figs. 1(b) and 2(b). The dependence on the IMF- $B_{x}$ is opposite between vernal equinox and autumnal equinox. This seasonal dependence is exactly the same with the result obtained by Potapova and Shapiro (1974), Triskova (1982), and Bremer (1988), and it has been interpreted by the Russell and McPherron effect which explains the IMF polarity effect on the geomagnetic disturbance. However, it is more reasonable to explain the IMF sector dependence as the solar activity effect rather than as the geomagnetic activity effect modulated by the Russell-McPherron effect, because the foF2 is directly controlled by the solar EUV flux which correlates with the solar activity as measured by the SRF or the SSN.

It is also reasonable that the electric fields as observed by the MU radar show the IMF- $B_{x}$ (or sector) dependence, because they would be modulated by the ionospheric conductivities or the thermospheric neutral winds, both of which are controlled by the solar activity having correlation with the IMF- $B_{x}$ in several years. The origin of the correlation between the solar activity and the sector structure for the period used in this paper is not clear and need further investigation using more extended data set of the IMF and SRF (or SSN) with some other solar surface observations such as the coronal holes. 


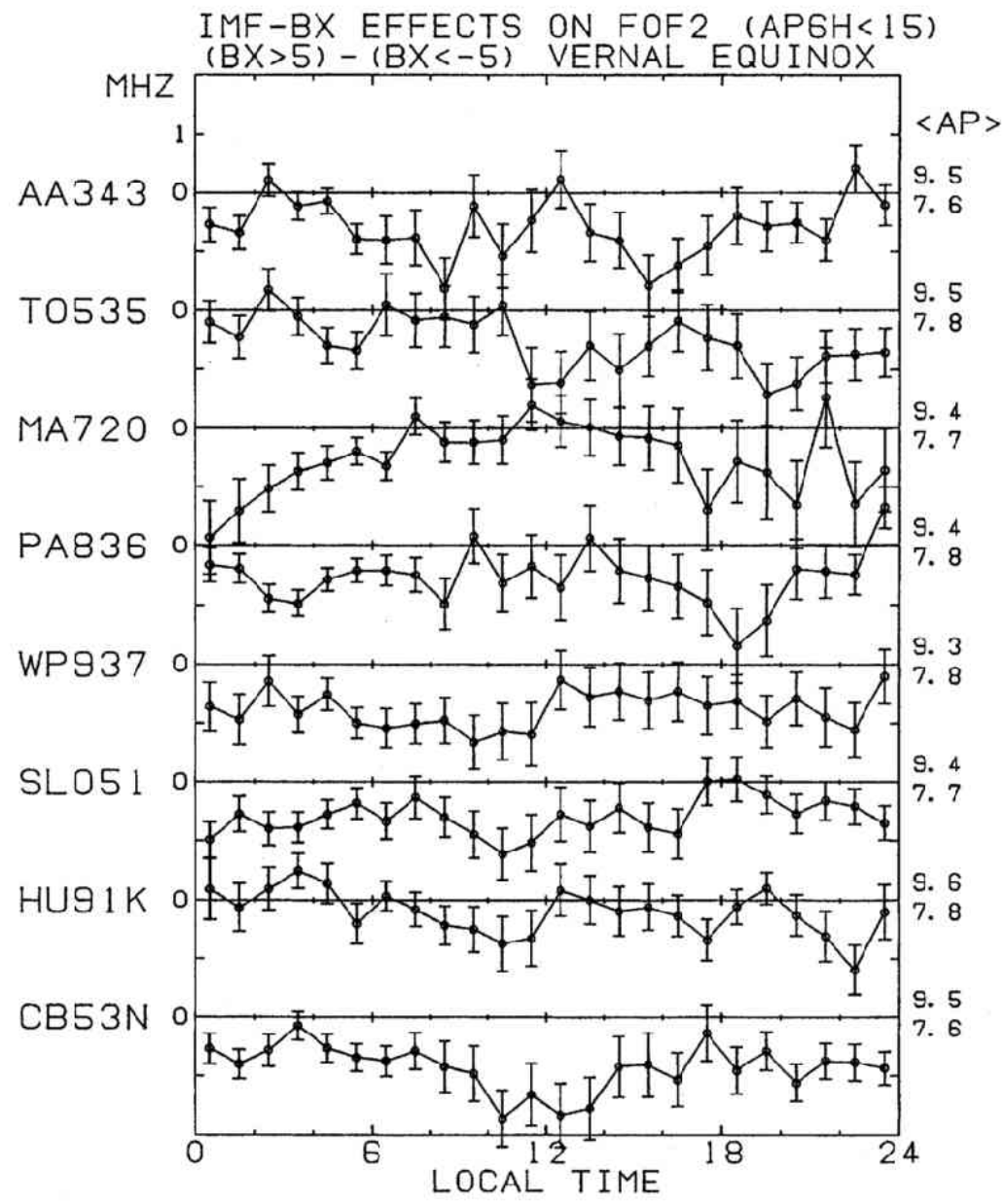

(a)

Fig. 1. The local time dependence of the difference in foF2 between positive (toward) and negative (away) IMF polarity at each station listed in Table 1 . (a) is for vernal equinox and (b) is for autumnal equinox. The average $a p$ values are shown on the right-side of each plot. The upper and lower values correspond to the cases for IMF- $B_{x}>5 \mathrm{nT}$ and $<-5 \mathrm{nT}$, respectively.

\subsection{Control of the electric field by the IMF and geomagnetic activity}

4.2.1. IMF- $B_{x}$ (or $B_{y}$ ) effect

Matsushita (1975), Shiraki (1975), and Butcher (1982) found the IMF sector polarity dependence of the focal latitude of the $S_{q}$ (solar daily quiet) current. In the polar region, the DPY current system is controlled by the IMF- $B_{y}$ (e.g., Friis-Christensen et al., 1985). The polar rain is also controlled by the IMF sector polarity (Fairfield and Scudder, 1985; Makita and Meng, 1987). Gonzalez and Gonzalez (1980) and Taguchi and Hoffman (1995) reported the existence of the IMF- $B_{x}$ effect on magnetopause reconnection. However, it is not clear that which (i.e., IMF- $B_{x}$ or $B_{y}$ ) essentially controls the intensity of the polar rain or the location of the $S_{q}$ current focus nor what mechanism is working in such IMF- $B_{x}$ (or $B_{y}$ ) effects.

The sense of ionospheric Hall currents estimated from the IMF- $B_{x}$ (or $B_{y}$ ) dependence of the $E_{s}$ component, the regression coefficient of which is mostly positive on the day-side (see 


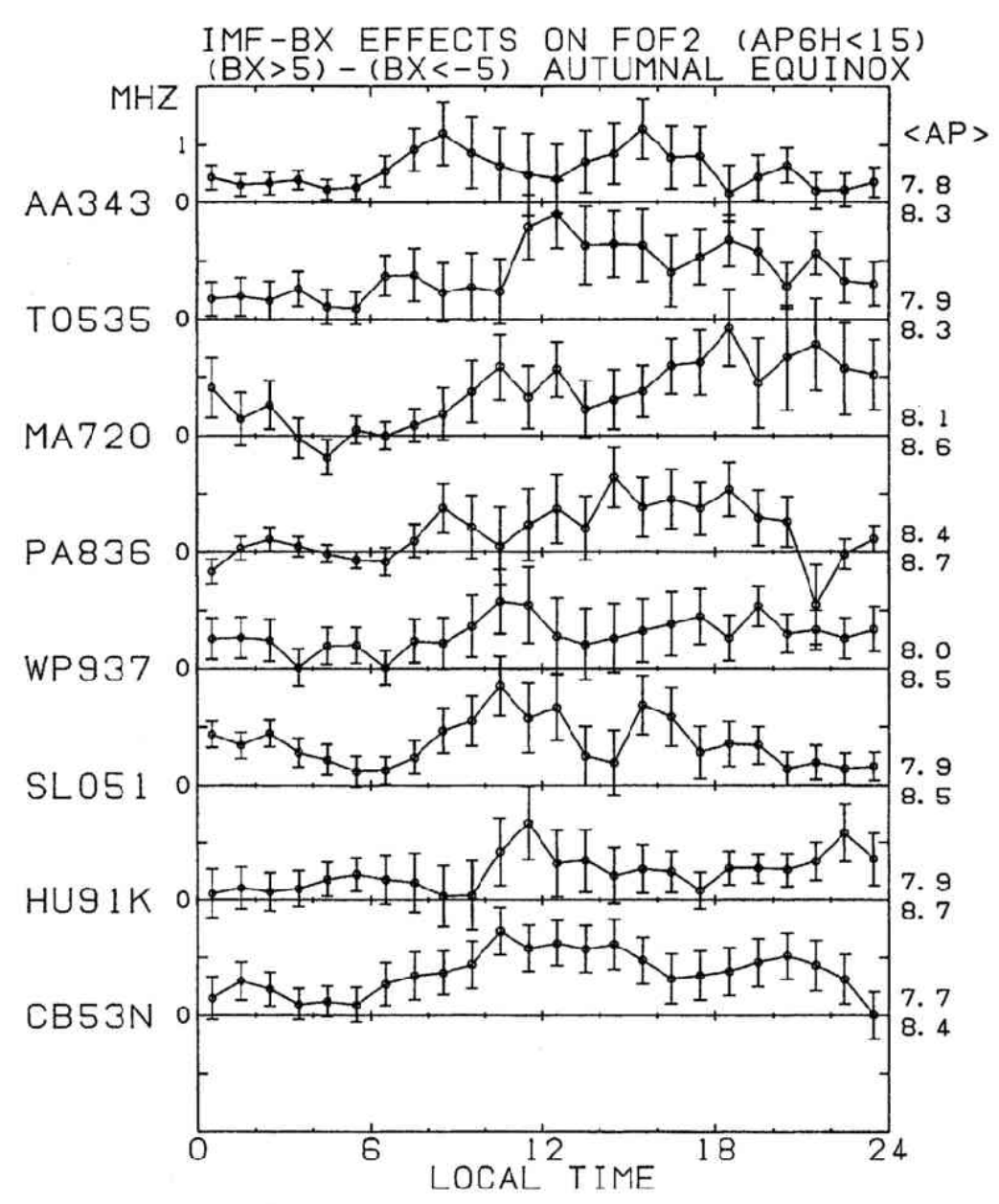

(b)

Fig. 1. (continued).

Tables 4(a) and 4(b)), is consistent with the IMF sector polarity dependence of the $S_{q}$ current system (Matsushita, 1975; Shiraki, 1975; Butcher, 1982), because the additional westward (Hall) current generated by the southward electric field, which would lower the $S_{q}$ focal latitude, is expected for the toward sector $\left(B_{x}>0\right)$ from the regression coefficients obtained in this study. However, the generation (penetration) mechanism of the electric field is not clear, though it can be said that the response time is less than one hour because we find the correlation in the differentials of the hourly data.

\subsubsection{IMF-B $B_{z}$ effects}

Table 4(c) shows a significant correlation between the IMF- $B_{z}$ and $E_{s}$ on the evening side and early morning side. On the evening side, if the electric field is mapped along the geomagnetic field lines of force, it points dusk-side on the magnetospheric equatorial plane for southward IMF, and it is also in the dusk-ward on the morning side(00-02 or 04-06 LT). This tendency is consistent with the IMF- $B_{z}$ dependence of the dawn-to-dusk electric field in the magnetosphere suggesting that the plasmaspheric shielding is not perfect for the fluctuations with time scale of 


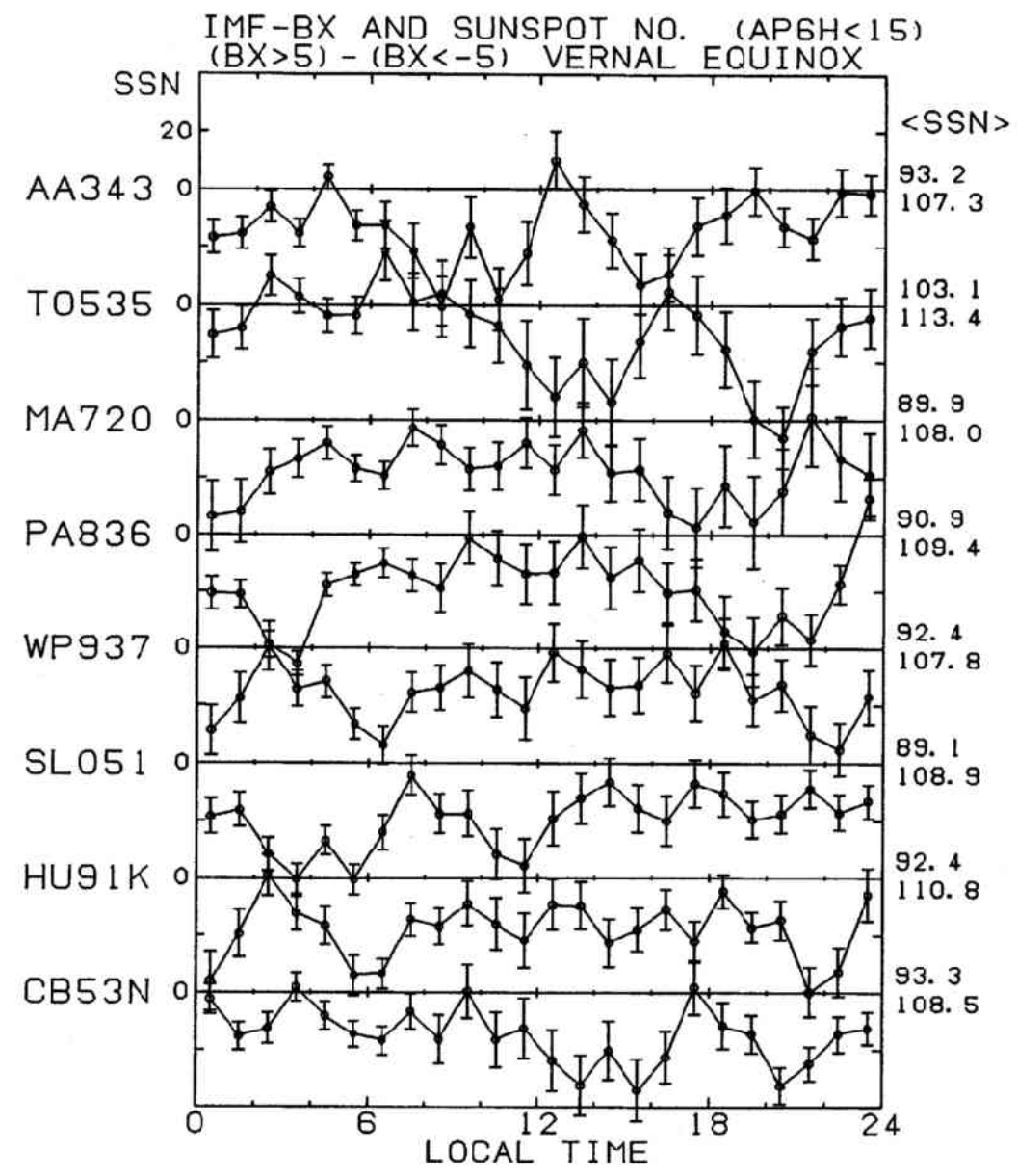

(a)

Fig. 2. The local time dependence of the difference in sunspot number between positive (toward) and negative (away) IMF polarity at each stations. (a) is for vernal equinox and (b) is for autumnal equinox. The average SSN are shown on the right-side of each plot. The upper and lower values correspond to the cases for $\mathrm{IMF}-B_{x}>5 \mathrm{nT}$ and $<-5 \mathrm{nT}$, respectively. Note the similarity between Figs. 1(a) and 2(a) (or 1(b) and 2(b)).

one hour (e.g., Southwood and Wolf, 1978; Blanc, 1983b). The high correlation of the eastward component, $E_{e}$, with IMF- $B_{z}$ in mid-night sector is also explained by the imperfect shielding of the dawn-dusk electric field of the magnetospheric origin.

\subsubsection{Geomagnetic activity effects}

In the pre-noon sector (06-12 LT), we find a high correlation probability between the geomagnetic disturbance indices and the electric field $E_{s}$ (see Table 3(a)). In particular, at 06-08 LT, it is much better than that with IMF indicating that the geomagnetic disturbance effect on the electric field does exist. The sense of dependence is that the northward component of the electric field increases as the geomagnetic disturbance develops. This tendency is generally the same in other local times and consistent with the results obtained by Blanc and Richmond (1980) who explained the geomagnetic dependence by the thermospheric circulation enhanced in the disturbed periods (i.e., ionospheric disturbance dynamo). On the other hand, significant correlation with 


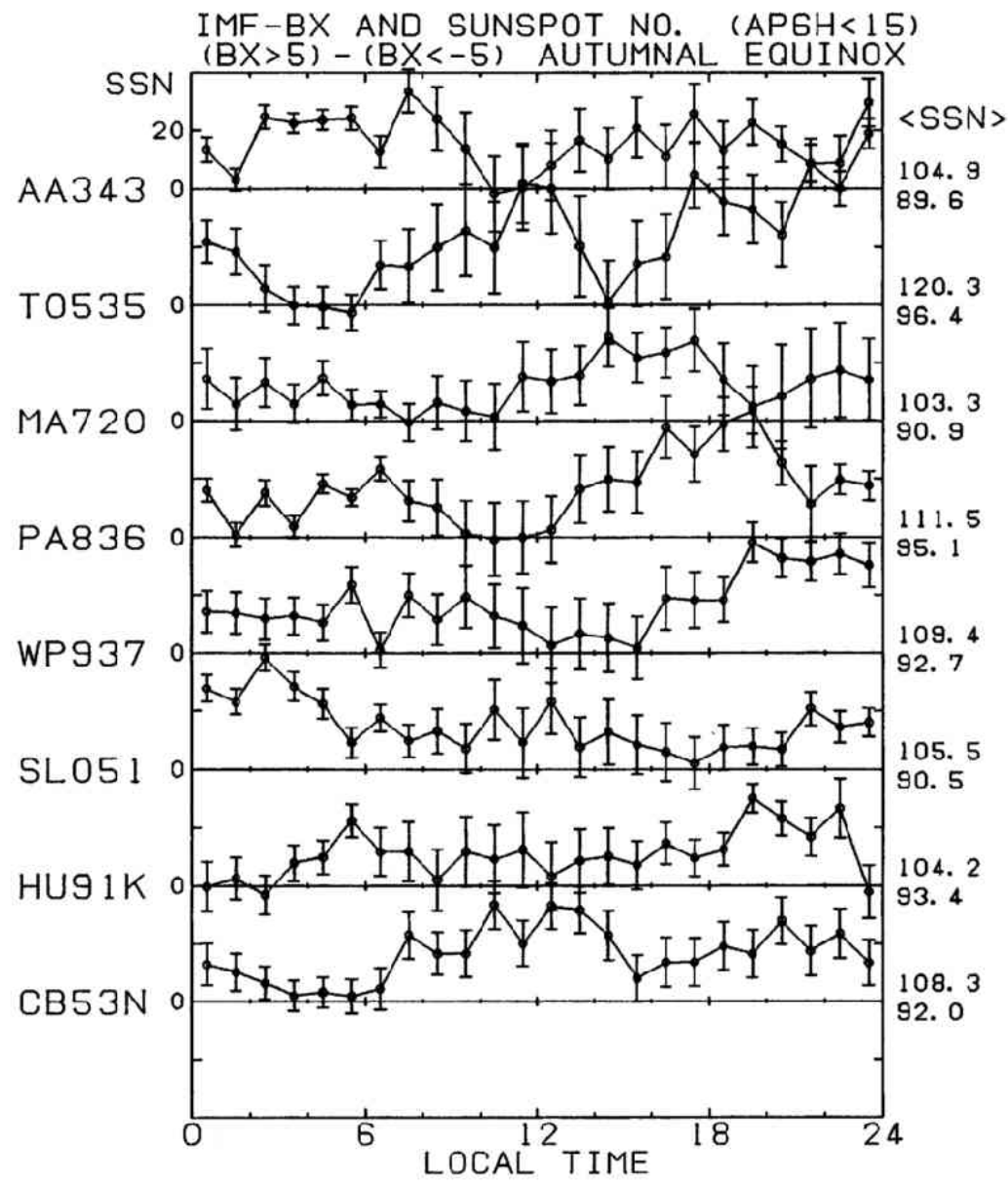

(b)

Fig. 2. (continued).

the Ee was only seen in 06-08 LT and some other local times.

\section{Conclusion}

The results are summarized as follows:

(1) Both the IMF- $B_{x}$ component and the Ottawa $2800 \mathrm{MHz}$ solar radio flux (SRF) correlates with the north-south component of the electric field on the night-side. For more positive (i.e., sunward) IMF- $B_{x}$, or for greater SRF, the electric field is more southward/downward in the northern hemisphere.

(2) The IMF- $B_{x}$ (sector polarity) and the SRF strongly correlate even if the statistics are taken for the period of several years, and most of the night-side correlation between the electric fields and the IMF- $B_{x}$ come from the effect of the solar activity rather than the direct influence of the IMF- $B_{x}$.

(3) By taking the correlation between time differentials of the parameters, the direct effects of the IMF- $B_{x}$ and/or the IMF- $B_{y}$ on the electric fields were also detected. The IMF- $B_{x}$ or $B_{y}$ 
has a significant correlation with electric fields on the dayside and its sense is consistent with the IMF effect on the $S_{q}$ focal location found by Matsushita (1975) and Shiraki (1975). The IMF- $B_{z}$ has significant correlation in limited local time zones and the direction of the electric field is consistent with the penetration of the dawn-to-dusk electric field of the magnetosphere, indicating the imperfect shielding in the plasmasphere for the time scale about one hour.

(4) The local time variation of the IMF- $B_{x}$ (or $B_{y}$ ) dependence of the foF 2 are very similar with that of the solar activity dependence suggesting that the mutual correlation between the solar activity and the IMF- $B_{x}$ (or $B_{y}$ ) causes the apparent correlation of the foF 2 with the IMF- $B_{x}$ which has been discussed as a sector structure effect.

(5) The cause of the correlation between the sector polarity at the Earth's orbit and the activity on the solar surface and its meaning in solar physics should be investigated.

We thank S. Fukao, T. Tsuda, M. Yamamoto and other staffs at Radio Atmospheric Science Center for providing the opportunity to conduct the study on the mid-latitude electric fields using the MU radar. We also thank T. Kamei, W. L. Oliver and K. Schlegel for their useful discussions. The software to process the raw data from MU radar observation was originally developed by $\mathrm{T}$. Saryo. The IMF data were obtained from the OMNI database at NASA/NSSDC and the $K_{p}$ index was supplied by Inst. for Geophys., Gottingen.

\section{REFERENCES}

Bevington, P. R., Data Reduction and Error Analysis for the Physical Science, pp. 119-133, McGraw-Hill, New York, 1969.

Blanc, M., Magnetospheric convection effects at mid-latitudes 1. Saint-Santin observations, J. Geophys. Res., 88, 211-223, 1983a.

Blanc, M., Magnetospheric convection effects at mid-latitudes 3. Theoretical derivation of the disturbance convection pattern in the plasmasphere, J. Geophys. Res., 88, 235-251, 1983b.

Blanc, M. and A. D. Richmond, The ionospheric disturbance dynamo, J. Geophys. Res., 85, 1669-1686, 1980.

Bremer, J., The influence of the IMF structure on the ionospheric F-region, J. Atmos. Terr. Phys., 50, 831-838, 1988.

Butcher, E. C., An investigation of the causes of abnormal quiet days in $S_{q}(H)$, Geophys. J. R. astr. Soc., 69, 101-111, 1982

Fairfield, D. H. and J. D. Scudder, Polar rain: Solar coronal electrons in the Earth's magnetosphere, J. Geophys. Res., 90, 4055-4068, 1985.

Friis-Christensen, E., Y. Kamide, A. D. Richmond, and S. Matsushita, Interplanetary magnetic field control of high-latitude electric ficlds and currents determined from Greenland magnetometer data, J. Geophys. Res., 90, 1325-1338, 1985.

Fukao, S., T. Sato, T. Tsuda, S. Kato, K. Wakasugi, and T. Makihara, The MU radar with an active phased array system, 1, Antenna and power amplifiers, Radio Sci., 20, 1155, 1985.

Ganguly, S., R. A. Behnke, and B. A. Emery, Average electric field behavior in the ionosphere above Arecibo, J. Geophys. Res., 92, 1199-1210, 1987.

Gonzalez, W. D. and A. L. C. Gonzalez, Influence of the $B_{x}$ component of the interplanetary magnetic field on magnetopause reconnection, Geophys. Res. Lett., 7, 773-776, 1980.

Iyemori, T., Storm-time magnetospheric currents inferred from mid-latitude geomagnetic field variations, J. Geomag. Geoelectr., 42, 1249-1265, 1990.

Iyemori, T., T. Araki, T. Kamei, and M. Takeda, Mid-latitude geomagnetic indices ASY and SYM (Provisional) 1989-1990, No. 1, pp. i-xi, Data Analysis Center for Geomag. and Space Mag., Kyoto Univ., Kyoto, 1992.

King, J. H., Interplanetary Medium Data Book-Supplement 4, 1985-1988, NSSDC/WDC-A-R \& S 89-17, 1989.

Makita, K. and C.-I. Meng, Long-period polar rain variations, solar wind and hemispherically symmetric polar rain, J. Geophys. Res., 92, 7381-7393, 1987.

Matsushita, S., IMF polarity effects on the $S_{q}$ current focus location, J. Geophys. Res., 80, 4751-4754, 1975.

Mayaud, P. N., Derivation, meaning, and use of geomagnetic indices, Geophys. Monograph 22, pp. 40-53, AGU, Washington, D.C., 1980.

Nishida, A., Coherence of geomagnetic DP2 fluctuations with interplanetary magnetic variations, J. Geophys. Res., 73, 5549-5559, 1968.

Oliver, W. L., Y. Yamamoto, T. Takami, S. Fukao, and T. Tsuda, Middle and upper atmosphere radar observations of ionospheric electric fields, J. Geophys. Res., 98, 11615-11627, 1993. 
Potapova, N. I. and T. J. Shapiro, Effect of the sector structure of the interplanetary magnetic field on the ionospheric F2 layer at middle latitudes, Geomag. Aeron., 14, 927-928, 1974.

Russell, C. T. and R. L. McPherron, Semiannual variation of geomagnetic activity, J. Geophys. Res., 78, 92-108, 1973.

Saryo, T., M. Takeda, T. Araki, T. Sato, T. Tsuda, S. Fukao, and S. Kato, Ion drift measured by the MU radar and its comparison with geomagnetic field variation, J. Geomag. Geoelectr., 41, 597-611, 1989.

Shiraki, M., Correlation study on day-to-day changes of geomagnetic solar daily variation and parameters of IMF sector structure and others, Mem. Kakioka Magnetic Obs., 16, 111-120, 1975.

Southwood, D. J. and Wolf, R. A., An assessment of the role of precipitation in magnetospheric convection, J. Geophys. Res., 83, 5227-5232, 1978.

Sugiura, M. and T. Kamei, Equatorial $D_{s t}$ index 1957-1986, IAGA Bulletin No. 40, ISGI Pub. Office, 1991.

Taguchi, S. and R. A. Hoffman, Bx control of polar cap potential for northward interplanetary magnetic field, $J$. Geophys. Res., 100, 19313-19320, 1995.

Triskova, L., Effects of IMF polarity on the F2-region, J. Atmos. Terr. Phys., 44, 37-41, 1982. 